\title{
Strategic Environmental Assessment (SEA): An introductory episode for Forestry Sector in Nepal
}

\author{
Tej Kumar Shrestha ${ }^{1}$ \\ Email : tejthaiva@lens.com.np
}

\section{What is Strategic Environmental Assessment (SEA)?}

According to Sadler and Verheem 1996 "SEA is a systematic process for evaluating the environmental consequences of proposed policy, plan or programme initiatives in order to ensure they are fully included and appropriately addressed at the earliest appropriate stage of decision making on par with economic and social considerations". It is in other words a form of Environmental Impact Assessment (EIA) for policy, plan and programme keeping in mind that evaluating environmental impacts at a strategic level is not necessarily the same as evaluating them at a project level (Therivel, 2010).

SEA is increasingly discussed in the literature but current reviews fail to explain specifically why certain assessments are strategic and how they differ from those that are non-strategic. Therivel and patridario (1996) for example "assume" that SEA addresses the "strategic component in decision instruments at the policy, plan or programme level", but they fall short inadequately addressing the meaning of "strategic". Number of definitions proposed in recent years acknowledges that SEA involves the early consideration of environmental issues in policy, plan and programmes decision making. There is no clear consensus for definition of SEA based on its strategic characteristics.

SEA offers a foundation on which to base environmental decision making to ensure the full consideration of alternative options at an early stage at a point where there is greater flexibility with respect to decision options. SEA is set in the context of broader visions, goals and objectives, helping choose a strategy for action and the least negative means to an envisioned end to enable environmental impacts to be avoided or minimized at the earliest possible stage of the decision making process (Therivel, 2010).

According to tenth Plan "The subject matter of environment protection is a crosscutting issue and it affects all the developmental activities; therefore, while making any policy arrangements, the process of the strategic environment assessment will be made strong". There is a strong expression and commitments from the government towards the strategic action on the protection of environment (Shrestha, 2007).

Managing Director, Lumbini Environment Services, Nepal 


\section{Aims and Principles of SEA}

The ultimate aim of SEA is to help to protect the environment and promote sustainability. No doubt there are many ways of doing this, but SEA contributes to this by helping to integrate environmental issues in decision making (Therivel, 2010).

1. SEA is the tool for improving Strategic action, not a post-hoc snapshot. The strategic action may well be changed as a result of SEA, with different objectives, different means of achieving these objectives and different forms of implementation. This suggests that the SEA should be started early, be integrated in the decision making process, and focus on identifying possible alternatives and modifications to the strategic action. The decision maker should be involved in the SEA process in an active capacity, to ensure that the SEA findings are fully taken into account in decision making (Sadler \& Verheem, 1996).

2. SEA should promote participation of other stakeholders in the decision making process. SEA should involve a range of stakeholders normally including the public. It should also document what has been done, why decisions have been made and assumptions and uncertainties.

3. SEA should focus on key environmental sustainability constraints thresholds and limits at the appropriate plan making.

4. SEA should help to identify the best option for the strategic action. It should thus assist in identifying and assessing different plan options for instance options that meet demands but minimize damage and options for demand management, modifying forecast demand rather than accommodating it.

5. SEA should aim to minimize negative impacts, optimize positive ones and compensate for the loss of valuable features and benefits.

6. SEA should ensure that strategic actions do not exceed limits beyond which irreversible damage from impacts may occur. 
Policies, Plans, Programmes and Tiering

Table 1: Examples for Environment Assessment for Policies, Plans, Programmes and Projects in Forestry sector.

\begin{tabular}{|c|c|c|}
\hline $\begin{array}{l}\text { Level of } \\
\text { strategy }\end{array}$ & $\begin{array}{c}\text { Environmental } \\
\text { Assessment } \\
\text { implemented }\end{array}$ & Examples of strategic actions \\
\hline Policies & SEA & $\begin{array}{l}\text { Land Use Policy } \\
\text { Objectives: } \\
\text { 1. Retain at least } 40 \% \text { of forest area in order to } \\
\text { maintain ecological balance }\end{array}$ \\
\hline Plans & SEA & $\begin{array}{l}\text { Master plan for forestry sector } 1989 \\
\text { Objectives: } \\
\text { 1. To ensure regular supply of forest products and } \\
\text { the support in maintaining environmental balance } \\
\text { by developing forest, plant resources, and } \\
\text { watershed and by conservation of biodiversity } \\
\text { and development of forest based industries. }\end{array}$ \\
\hline Programmes & SEA & $\begin{array}{l}\text { 1. Community and private forestry development } \\
\text { 2. The national and leasehold forestry development } \\
\text { programme } \\
\text { 3. The medicinal and aromatic plant and other } \\
\text { minor forest product development programme } \\
\text { 4. The soil conservation and watershed } \\
\text { management programme } \\
\text { 5. The wood based industries programme } \\
\text { 6. Ecosystem and genetic resource conservation } \\
\text { programmes }\end{array}$ \\
\hline Projects & $\begin{array}{l}\text { Initial } \\
\text { Environmental } \\
\text { Examination } \\
\text { (IEE)/ } \\
\text { Environmental } \\
\text { Impact } \\
\text { Assessment } \\
\text { (EIA) }\end{array}$ & $\begin{array}{l}\text { 1. Handover of the forests as community forest. } \\
\text { 2. Handover of forests as leasehold forests. } \\
\text { 3. Establishment of medicinal herbs centres for the } \\
\text { commercial production of medicinal herbs and } \\
\text { aromatic plants in public scrublands. } \\
\text { 4. Formulation of watershed management plans. } \\
\text { 5. Establishment of saw-mills processing more than } \\
\text { 5,000 } \\
\text { 6. Construction of new botanical gardens or zoos } \\
\text { outside forest areas in the public or private } \\
\text { sector. }\end{array}$ \\
\hline
\end{tabular}


The table 1 adapted from Lee and Wood (1987) and modified by taking land use policy of Nepal illustrates the tier of Strategic actions and Environmental Assessment required in each tier. Land Use Policy of Nepal is the policy level task which requires SEA, followed by ten years Forestry Master Plan 1989, which comprises six different programmes as its components which require SEA. At the project level IEE and EIA is legislative requirement depending upon the magnitudes of significant impacts from the project. Environmental Protection Rules 1997 has made IEE and EIA a mandatory for major development proposals.

\section{Reference}

GON. 1997. Environmental Protection Rules. GON.

GON. 1989. Master Plan for Forestry Sector. Kathmandu: GON.

Lee, N., \& Wood, C. 1987. EIA: A European Perspective. Built environment , 101-110.

NPC. 2002. The Tenth National Plan (2002-2007). National Planning Commission.

Sadler, B., \& Verheem, R. 1996. SEA: Status, Challenges and Future Directions, Report 53. Spatial Planning and the Environment, Ministry of Housing. Netherlands: the Hague.

Shrestha, T. K. 2007. Assessing Feasibility of Environmental Assessment within Community forestry: Stakeholder's Perception in Nepal. Norwich: University of East Anglia.

Therivel, R. 1996. Environmental Appraisal of Development Plans: Status in late 1995. report.

Therivel, R. 2010. Strategic Environmental Assessment in Action(First ed.). London: Earthscan. 